\title{
PROBLEMATIKA MEDIASI DALAM KASUS PERCERAIAN DI MAHKAMAH SYAR'IYAH LANGSA
}

\author{
Wirda Hairani dan Syawaluddin Ismail \\ Dosen Hukum Islam Fakultas Syariah IAIN Langsa \\ E-mail syawaluddin ismail@iainlangsa.ac.id
}

\begin{abstract}
This study wants to see the problem of mediation in divorce cases at the Langsa Mahkamah Syar'iyah. The procedure for conducting mediation in the court as regulated in PERMA Number 02 of 2003 was found to be a problem originating from PERMA itself. Then MA revised PERMA Number 02 of 2003 with PERMA Number 01 of 2008. After a long period of time it turned out that PERMA Number 01 of 2008 had its shortcomings, namely the mediation procedure in the court had not optimally fulfilled the need for mediation and increased the success of mediation in court. The Supreme Court decided to issue the latest regulation again, namely PERMA Number 01 of 2016.
\end{abstract}

Keywords: PERMA, Mediation, Divorce.

\begin{abstract}
Abstrak: Penelitian ini ingin melihat problematika mediasi dalam kasus perceraian di Mahkamah Syar'iyah Langsa. Prosedur pelaksanaan mediasi di pengadilan sebagaimana yang di atur dalam PERMA Nomor 02 Tahun 2003 ternyata ditemukan permasalahan yang bersumber dari PERMA itu sendiri. Kemudian MA merevisi PERMA Nomor 02 Tahun 2003 dengan PERMA Nomor 01 Tahun 2008. Setelah cukup lama berjalannya ternyata PERMA Nomor 01 Tahun 2008 ada kekuranganya yaitu prosedur mediasi di pengadilan belum optimal memenuhi kebutuhan pelaksanaan mediasi yang lebih berdayaguna dan mampu meningkatkan keberhasilan mediasi di pengadilan, maka Mahkamah Agung memutuskan untuk menerbitkan peraturan terbarunya lagi yaitu PERMA Nomor 01 Tahun 2016.
\end{abstract}

Kata kunci: PERMA, Mediasi, Perceraian

\section{Pendahuluan}

Sebagaimana telah diketahui, bahwa peradilan dapat diidentifikasikan sebagai bagian dari pranata hukum, sedangkan hukum dapat di identifikasikan sebagai pranata sosial. Hukum bukanlah sematamata sekedar sebagai pedoman untuk dibaca, dilihat atau diketahui saja, melainkan hukum dilaksanakan atau ditaati. Hukum harus dilaksanakan oleh segenap komponen dalam suatu negara hukum.

Negara Indonesia adalah Negara hukum, demikianlah amanat yang diberikan oleh konstitusi Negara Indonesia yaitu UUD Tahun 1945 dalam Pasal 1 Ayat (3). Tahap pertama yang dilaksanakan oleh hakim dalam menyidangkan suatu perkara yang di ajukan kepadanya adalah mengadakan perdamaian kepada pihak-pihak bersengketa. Sebelum kita membahas tentang mediasi, maka ada baiknya jika kita mengetahui dulu definisi dari mediasi.

Dalam pasal 1851 KUHPerdata dikemukakan bahwa yang dimaksud dengan perdamaian adalah suatu persetujuan di mana kedua belah pihak dengan menyerahkan, menjanjikan atau menahan suatu barang, mengakhiri suatu perkara yang sedang bergantung atau mencegah timbulnya suatu perkara. Persetujuan perdamaian tidak sah melainkan harus dibuat secara tertulis. Dan kemudian dalam pasal 130 Herziene Inland Reglemend (yang selanjutnya disebut HIR) dan pasal 154 Rechtsreglement Voor De Buitengewesten (yang selanjutnya disebut R.Bg) dikemukakan bahwa jika pada hari persidangan yang telah di tetapkan kedua belah pihak yang berpekara hadir dalam persidangan maka ketua majlis hakim 
berusaha mendamaikan pihak-pihak yang bersengketa tersebut.

Tentang hal yang berhubungan dengan perceraian dikemukakan dalam pasal 65 dan 82 undang-undang Nomor 71987 jo (yang di sebut dengan juncto). Pasal 39 UU No 1 Tahun 1974 jo. Pasal 31 peraturan pemerintah No 9 Tahun 1975. Dalam pasal-pasal ini dikemukakan bahwa hakim wajib mendamaikan para pihak yang berpekara sebelum putusan dijatuhkan. Dalam PERMA Nomor 1 Tahun 2016 disebutkan bahwa pengertian mediasi adalah cara penyelesaian sengketa melalui proses perundingan untuk memperoleh kesepakatan para pihak dengan di bantu oleh Mediator. ${ }^{1}$ Jelaslah bahwa mediasi adalah merupakan jalan alternatif untuk menyelesaikan sengketa diluar pengadilan. Mediasi memberikan jalan keluar untuk para pihak menyelesaikan sengketanya dengan solusi terbaik di luar jalur pengadilan.

Usaha hakim mendamaikan pihak-pihak yang berpekara itu dapat dilakukan pada setiap sidang pemeriksaan. Dalam upaya mendamaikan itu hakim wajib menghadirkan pihak keluarga atau tetangga dekat pihak-pihak yang berpekara untuk didengar keteranganya dan meminta bantuan agar pihak-pihak berpekara itu rukun kembali. ${ }^{2}$

Dilihat dari ketentuan yang terdapat dalam pasal $130 \mathrm{HIR} /$ pasal $154 \quad \mathrm{R} . \mathrm{Bg}$, maka MA memodifikasikan ketentuan tersebut kearah yang lebih bersifat memaksa. Beranjak dari apa yang telah dirumuskan dalam ketentuan tersebut maka MA pada tanggal 11 september 2003 mengeluarkan peraturan Mahkamah Agung (yang selanjutnya disebut PERMA) Nomor 2 Tahun 2003 dengan judul prosedur mediasi di pengadilan. Terdapat dalam konsideransnya pada hurup e dikatakan bahwa salah satu alasan mengapa PERMA diterbitkan karena surat edaran Mahkamah Agung (yang selanjutnya disebut SEMA) Nomor 1 Tahun 2002 belum lengkap mengatur tentang prosedur

1 Ketua Mahkama Agung Republik Indonesia, Peraturan Mahkamah Agung Nomor 1 Tahun 2016 Tentang Prosedur Mediasi di Pengadilan.

${ }^{2}$ Abdul Manan, Penerapan Hukum Acara Perdata Di Lingkungan Peradilan Agama, (Jakarta: Kencana, 2008), hal. 152-153. mediasi, atas dasar alasan bahwa SEMA belum sepenuhnya mengintegrasikan mediasi kedalam sistem peradilan secara memaksa melainkan hanya bersifat sukarela dan akibatnya SEMA tersebut tidak mampu mendorong para pihak secara intensif untuk memaksakan penyelesaian perkara melalui mediasi terlebih dahulu.

Setelah dilakukannya evaluasi terhadap prosedur pelaksanaan mediasi di pengadilan sebagaimana yang di atur dalam PERMA Nomor 02 Tahun 2003 ternyata ditemukan permasalahan yang bersumber dari PERMA itu sendiri. Kemudian untuk memberdayakan mediasi yang dilakukan di pengadilan, MA merevisi PERMA Nomor 02 Tahun 2003 dengan PERMA Nomor 01 Tahun 2008 tentang prosedur mediasi di pengadilan. Setelah cukup lama berjalannya PERMA Nomor 01 Tahun 2008 tentang prosedur pelaksanaan mediasi di pengadilan, Mahkamah Agung memutuskan untuk menerbitkan peraturan terbarunya yaitu PERMA Nomor 01 Tahun 2016 tentang prosedur mediasi di pengadilan, MA menganggap bahwa PERMA Nomor 01 Tahun 2008 tentang prosedur mediasi di pengadilan belum optimal memenuhi kebutuhan pelaksanaan mediasi yang lebih berdayaguna dan mempu meningkatkan keberhasilan mediasi di pengadilan. Berdasarkan hal tersebut Mahkamah Agung memutuskan untuk mengeluarkan PERMA Nomor 01 Tahun 2016 untuk mencabut PERMA Nomor 01 Tahun 2008 dengan harapan menaikan tingkat keberhasilan dalam mediasi.

\section{Tinjauan Yuridis Syarat Formal dalam Upaya Mediasi}

Mahkamah Agung adalah lembaga Tinggi Nengara dalam sistem ketata negaraan Indonesia yang merupakan pemegang kekuasaan kehakiman, Mahkamah Agung membawahi badan peradilan dalam lingkungan peradilan umum, peradilan agama, peradilan militer, peradilan tata usaha negara. Menjadi kekuasaan dan kewenangan Mahkamah Agung yang berkaitan dengan pengawasan secara tidak langsung adalah dengan menerbitkan peraturan. ${ }^{3}$ Kewenangan itu telah

\footnotetext{
${ }^{3}$ Kevin Angkouw, "Fungsi Mahkamah Agung Sebagai Pengawas Internal Tugas Hakim Dalam Proses Problematika Mediasi Dalam Kasus Perceraian|39
} 
ditegaskan pada angka 2 huruf c penjelasan umum Undang-undang Nomor 48 Tahun 2009 Tentang perubahan atas Undang-undang Nomor 14 Tahun 1985 Tentang Mahkamah Agung yang berbunyi: ${ }^{4}$

"Membuat peraturan sebagai pelengkap untuk mengisi kekuarangaan atau kekosongan hukum yang diperlukan bagi kelancaran jalannya peradilan”.

Jika ditinjau bedasarkan ketentuan peraturan perundang-undangan sebagaimana yang ditetapkan pada Pasal 8 Ayat (1) dan (2) Undang-undang Nomor 12 Tahun 2011 Tentang pembentukan peraturan perundang-undangan, PERMA termasuk salah satu jenis ketentuan peraturan perundangundangan sebagaimana yang termaktub dalam Pasal 7 ayat (1) undang-undang Nomor 12 Tahun 2011 Tentang Pembentukan Peraturan PerundangUndangan Berbunyi Sebagai Berikut: ${ }^{5}$

Jenis dan hierarki peraturan perundang-undangan terdiri atas:

1. Undang-Undang Dasar Negara Republik Indonsia Tahun 1945:

2. Ketetapan Majlis Permusyawaratan Rakyat:

3. Undang-Undang/Peraturan Pemerintah Penggannti Undang-Undang:

4. Peraturan Pemerintah:

5. Peraturan Presiden:

6. Peraturan Daerah Provinsi: dan

7. Peraturan Daerah Kabupaten/Kota.

Demikianlah hierarki peraturan perundangundangan yang terdapat pada Pasal 7 Ayat (1) Undang-undang Nomor 12 Tahun 2011 Tentang Pembentukan Peraturan Perundang-Undangan. Namun apa yang telah ditentukan pada Pasal 7 Ayat (1) tersebut tidaklah bersifat final, sebagaimana terdapat pada Pasal 8 Ayat (2) undang-undang Nomor 12 Tahun 2011 Tentang pemebentukan peraturan perundang-undangan yang menyatakan bahwa peraturan perundang-undangan sebagaimana yang dimaksud pada Ayat (1) diakui keberadaannya dang mempunyai kekuatan hukum mengikat

Peradilan", Lex Administratum II, 2 (April-Juni 2014), hal. 1-2.

${ }^{4}$ Undang-Undang Nomor 48 Tahun 2009 Tentang Perubahan atas Undang-Undang Nomor 14 Tahun 1985 Teantang Mahkamah Agung.

5 Undang-Undang Nomor 48 Tahun 2009 Tentang Pembentukan Peraturan Perundang-undangan. sepanjang diperintanhkan oleh peraturan perundangundangan yang lebih tinggi atau dibentuk bedasarkan kewenangan.

Sebagaimana telah dikemukakan bahwa perdamaian itu adalah persetujuan dari kedua orang yang berpekara untuk menyerahkan, menjanjikan tau menahaan suatu barang, dengan maksud untuk mengakhiri seatu perkara, persetujuan perdamaian itu haruslah di buat secara tertulis. Sehubungan dengan hal ini, maka perdamaian yang dilaksanakan di muka persidangan haruslah timbal balik dalam pengorbanan dari para pihak-pihak yang berpekara. Tidak ada perdamaian apabila salah satu pihak mengalah begitu saja dan mengakui semua tuntutan pihak lawan seluruhnya tanpa reserve. Demikian jugak tidak ada perdamaian apabila arbritrase, atau juga setuju untuk tunduk pada suatu nasihat yang diberikan oleh pihak ketiga. ${ }^{6}$

Ketentuan formal dari suatu putusan perdamaian sebagaimanan tersebut dalam pasal 1851KUHPerdata, pasal 130 HIR dan pasal 154 R.Bg dapat dikemukakan sebagai berikut:

1. Adanya persetujuan kedua belah pihak

Langkah awal yang harus dilaksanakan oleh hakim dalm menyidangkan suatu perkara adalah mengadakan perdamaian para pihak yang bersengketa. Dalam perkara perceraian usaha mendamaikan para pihak dilaksanakan terusmenerus pada setiap persidangan sapai hakim menjatuhkan putusannya. ${ }^{7}$

Dalam usaha melaksakan perdamaian yang dilaksanakan oleh majlis hakim dalam persidangan, kedua belah pihak harus sepakat dan menyetujui dengan sukarela untuk mengakhiri perselisihan yang berlangsung. Persetujuan itu harus betul-betul murni datng dari kedua belah pihak dan tidak boleh ada paksaan dari pihak lain. Dengan demikian terhadap perjanjian perdamaian berlaku sepenuhnya unsurunsur persetujuan sebagaiamana yang tersebut dalam pasal 1320 KUHPerdata, yaitu: (1) danya kata sepakat secara sukarela atau toestemming, (2) kedua

\footnotetext{
${ }^{6}$ Abdul Manan, Penerapan Hukum Acara Perdata Di lingkungan Peradilan Agama, (Jakarta: Kencana, 2008), hal.154.

${ }^{7}$ Abdul Manan, Penerapan Hukum. hal. 154 Problematika Mediasi Dalam Kasus Perceraian|40
} 
belah pihak cakap membuat persetujuan atau bekwanneid, (3) objek persetujuan mengenai pokok yang tertentu atau bepaalde onderwerp, (4) berdasarkan alasan yang diperbolehkan atau georrlosofde oorzaak. Dengan hal ini, persetujuan yang dibuat itu tidak boleh terdapat cacat pada setiap unsur esensial persetujuan yang tersebut dalam asas umum tersebut. Persetujuan perdamaian itu sama sekali tidak boleh mengandung unsur kekeliruan (dwaling), paksaan (dwang) dan penipu (bedrog). Dalam pasal 1859 KUHPerdata ditegaskan pula bahwa putusan perdamaian itu dapat dibatalkan apabila terdapat kehilafan tentang orangnya atau perselishannya.

\section{Mengakhiri sengketa}

Dalam pasal 130 HIR dan pasal 154 R. $\cdot \mathrm{Bg}^{8}$ dikemukakan bahwa apabila perdamaian telah dapat dilaksanakan maka di buat putusan perdamaian yang lazim disebut dengan akta perdamaian. Akta perdamaian yang dibuat itu harus betul-betul mengakhiri sengketa yang terjadi antara kedua belah pihak yang berpekara. Apabila putusan perdamaian yang dibuat itu tidak dapat mengakhri sengketa antara pihak yang berpekara, maka putusan perdamaian itu dianggap tidak memenuhi syarat formal, dianggap tidak sah, dan tidak mengikat kepada pihak-pihak yang berpekara. ${ }^{9}$

\section{Perdamaian atas sengketa yang telah ada}

Dalam pasal 1851KUHPerdata dikemukakan bahwa untuk dapat dijadikan dasar putusan perdamaian itu hendaklah sengketaan para pihak sudah terjadi, baik yang sudah terwujud maupun yang sudah nyata terwujud tetapi baru akan diajukaan ke Pengadilan sehingga perdamaian yang dibuat oleh para pihak mencegah terjadinya perkara di sidang pengadilan. Berdasarkan pasal 1851 KUHPerdata diatas dapat dipahami bahwa perdamaian itu dapat lahir dari suatu sengketa perdata yang sedang diperiksa di dalam Pengadilan maupun yang belum diajukan ke pengadilan, atau

${ }^{8} \mathrm{HIR}$ yaitu Hukum acara dalam persidangan perkara Perdata maupun Pidana yang berlaku di pulau Jawa dan Madura. Sedangkan R.B.g yaitu Hukum acara yang berlaku di persidangan perkara Perdata maupun Pidana di Pengadilan luar Jawa dan Madura.

${ }^{9}$ Abdul Manan, Penerapan hukum..., hlm. 155. perkara yang sedang tergantung diPengadilan sehingga persetujuan Pengadilan perdamaian yang dibuat para pihak dapat mencegah terjadinya perkara di pengadilan. ${ }^{10}$

\section{Bentuk perdamaian harus tertulis}

Dalam pasal 1851 KUHPerdata juga dikemukakan bahwa persetujuan perdamaian itu sah jika dibuat secara tertulis. Syarat ini sifatnya (memaksa), jadi tidak ada persetujuan apabila dilaksanakan secara lisan dihadapan penjabat yang berwenang. Akta perdamaian harus dibuat tertulis sesuai dengan format yang ditetapkan oleh ketentuan yang berlaku.

Apabila ditinjau dari segi bentuk persetujuan perdamaian yang dihubungkan dengan tingkat cara pembuatan persetujuan perdamaian itu sendiri, maka dapat dibedakan dua bentuk persetujuan perdamaian, yaitu: ${ }^{11}$

\section{Putusan perdamaian}

Apabila pihak-pihak yang bersengketa mengadakan perdamaian terhadap suatu masalah yang disengketakan mereka membuat akta perdamaian secara tertulis. Para pihak yang bersengketa memohon kepada majlis hakim agar persetujuan perdamaian itu dikukuhkan dalam suatu keputusan yang disebut dengan putusan perdamaian. lat.

Jadi, dalam membuat putusan perdamaian itu haruslah terpisah dengan akta persetujuan perdamaian. Persetujuan damai dibuat sendiri oleh para pihak yang bersengketa, baru kemudian persetujuan perdamaian itu diajukan pada Pengadilan atau hakim yang menyidangkan perkara tersebut untuk dikukuhkan sebagai putusan perdamaian dengan memberikan titel eksekusi.

\section{Akta perdamaian}

Suatu persetujuan disebut berbentuk akta perdamaian, jika persetujuan perdamaian terjadi tanpa campur tangan Pengadilan atau hakim. Bentuk persetujuan perdamaian yang dituangkan dalam akta

\footnotetext{
${ }^{10}$ Abdul Manan, Penerapan hukum..., hlm 156.

${ }^{11}$ Abdul Manan, Penerapan hukum..., hlm 157. Problematika Mediasi Dalam Kasus Perceraian|41
} 
perdamaian itu dibuat sendiri oleh pihak-pihak yang bersengketa. Adapun cara membuatnya sangat sederhana yaitu para pihak yang bersengketa merumuskan sendiri persetujuan itu dengan tujuan untuk mengakhiri sengketa yang terjadi diantara mereka. Akta perdamaian ini dapat berbentuk akta autentik dan dapat pula dibuat dalam bentuk dibawah tangan. Agar tidak terjadi hal-hal yang tidak diharapkan dikemudian hari, sebaiknya akta perdamaian itu dibuat dalam bentuk akta autentik agar isi dan tanda tangan tidak bisa dipungkiri. Akta perdamaian ini tidak dapat dieksekusi, karena pembuatannya tidak melalui campur tangan Pengadilan tetapi di buat oleh notaris.

PERMA No 01 Tahun 2016 menyebutkan bahwa mediasi merupakan proses penyelesaian sengketa yang berada di luar pengadilan, proses mediasi memiliki ciri dan prinsip yang berbeda dengan prinsip pada persidangan pada umumnya, perbedaan tersebut diantaranya adalah:

1. Proses mediasi bersifat informal. Di mana Mediator bertindak sebagai fasilitator melakukan pendekatan-pendekatan non formal untuk meyelesaikan perkara, pelaksanaan mediasi ini diselengarakan di ruang mediasi Pengadilan atau tempat lain di luar Pengadilan yang di sepakati oleh para pihak. Sedangkan bagi Mediator hakim dan pegawai Pengadilan dilarang menyelengarakan mediasi di luar pengadilan, namun tingkat formalitasnya tidak seperti proses persidangan di pengadilan. Maka dengan demikian proses mediasi di Pengadilan lebih bersifat semi informal.

2. Waktu yang digunakan relatif singkat, namun dirasa cukup untuk melakukan mediasi. Pasal 24 Ayat (2) PERMA Nomor 1 Tahun 2016 menyebutkan bahwa proses mediasi berlangsung paling lama 30 (tiga puluh) hari terhitung sejak penetapan perintah melakukan mediasi. Dalam pasal 24 Ayat (3) dapat diperpanjang atas dasar kesepakatan para pihak, jangka waktu mediasi dapat diperpanjang paling lama 30 (tiga puluh) hari terhitung sejak berakhir jangka waktu sebagaimana dimaksud pada ayat (2).

3. Penyelesaian berdasarkan kesepakatan kedua belah pihak. Majlis hakim hanya sebagai fasilitator agar tercapainya kesepakatan antara kedua belah pihakyang bersengketa.

4. Tidak dikenakan biaya, jika mengunakan jasa Mediator hakim dan pegawai pengadilan, sedangkan dikenakan biaya jika mengunakan jasa Mediator non hakim dan bukan pegawai pengadilan, biayanya ditangung bersama atau berdasarkan kesepakatan para pihak. Dikenakan biaya hanya untuk pemanggilan para pihak, ruangan serta fasilitas yang ada di Pengadilan tidak dipungut biaya apapun. ${ }^{12}$ Dalam Pasal 5 ayat (1) disebutkan bahwa proses mediasi bersifat tertutup.

5. Kesepakatan damai bersifat mengakhiri perkara. Jika para pihak menghendaki perdamaian maka gugatan harus dicabut dan perkara dianggap selesai.

6. Hasil mediasi bersifat win-win solution. Antara kedua belah pihak tidak ada merasa kalah dan menang tetapi adalah sama-sama merasa ini yang terbaik.

7. Akta perdamaian yang di lakukan di Pengadilan bersifat final dan banding. Dan berkekuatan hukum tetap (BHT) dan dapat di eksekusi.

Tahapan pra mediasi Pengugat mendaftarkan perkaranya ke Pengadilan Agama yang akan dicatat di buku catatan register perkara dan di sampaikan ke ketua pengadilan. $^{13}$ Kemudian ketua Pengadilan akan membentuk majlis hakim yang akan memeriksa perkara tersebut, yang kemudian ditetapkannya hari sidang. Pada hari sidang yang telah ditentukan dan dihadiri oleh para pihak, hakim pemeriksa perkara mewajibkan para pihak untuk menempuh mediasi, kehadiran para pihak sebagaimana yang dimaksud ialah berdasarkan panggilan yang sah dan patut.

Pada sidang pertama para pihak yang bersengketa diwajibkan untuk menempuh jalur mediasi terlebih dahulu sebelum di periksa lebih lanjut. Hakim pemeriksa perkara wajib menjelaskan prosedur mediasi kepada para pihak dan menyerahkan formulir penjelasan medaisi kepada para pihak,

12 Putusan Pasal 8 Peraturan Mahkamah Agung Nomor 01 Tahun 2016 Tentang Biaya jasa Mediator.

13 Putusan Pasal 17 Peraturan Mahkamah Agung Nomor 01 Tahun 2016 Tentang tahapan pramediasi. Problematika Mediasi Dalam Kasus Perceraian|42 
selanjutnya keterangan mengenai penjelasan oleh hakim pemeriksa perkara dan penandatanganan formulir penjelasan mediasi sebagaimana dimaksud wajib dimuat dalam berita acara sidang. Setelah menjelaskan tentang prosedur medaisi, selanjutnya majlis hakim memberikan kesempatan untuk paraa pihak memilih seorang atau lebih Mediator yang tercatat dalam daftar Mediator di pengadilan.

Jika dalam 2 (dua) hari, para pihak tidak juga dapat menentukan siapa yang akan menjadi Mediator, maka majlis hakim akan menunjuk Mediator hakim atau pegawai Pengadilan yang bersertifikat Mediator. Jika pada Pengadilan yang sama tidak terdapat hakim bukan pemeriksa perkara dan pegawai Pengadilan yang bersertifikat, ketua majlis hakim pemeriksa perkara menunjuk salah satu hakim pemeriksa perkara untuk menjalankan fungsi Mediator dengan mengutamakan hakim yang bersertifikat.

Majlis hakim akan memberikan waktu selama 30 (tiga puluh) hari terhitung sejak penetapan perintah melakukan mediasi. Dalam pasal 24 Ayat (3) dapat diperpanjang atas dasar kesepakatan para pihak, jangka waktu mediasi dapat diperpanjang paling lama 30 (tiga puluh) hari terhitung sejak berakhirnya jangka waktu tahap pertama.

Dalam PERMA Nomor 1 Tahun 2016 ini menjelaskan tentang iktikad baik dalam mediasi dan akibat hukumnya, dijelaskan bahwa apabila Penggugat dinyatakan tidak beriktikad baik dalam proses mediasi sebagaimana dimaksud dalam pasal 7 ayat (2), gugatan dinayatakan tidak dapat diterima oleh hakim pemeriksa perkara dan akan dikenai kewajiban pembayaran biaya mediasi. Mediator menyampaikan laporan Penggugat tidak beriktikad baik kepada hakim pemeriksa perkara disertai rekomendasi pengenaan biaya mediasi dan perhitungan besarnya dalam laporan ketidakberhasilan atau tidak dapat dilaksanakannya mediasi, biaya mediasi sebagai penghukuman kepada Penggugat dapat di ambil dari panjar perkara ayau pembayaran tersendiri oleh Penggugat dan diserahkan kepada Tergugat melalui kepanitraan pengadilan.
Bagi Tergugat yang tidak beriktikad baik sebagaimana dimaksud dalam pasal 7 ayat (2), dikenai kewajiban pembayaran biaya mediasi, medaitor menyampaikan laporan Tergugat tidak beriktikad baik kepada hakim pemeriksa perkara disertai rekomendasi pengenaan biaya mediasi dan perhitungan besarannya dalam laporan ketidak berhasilan atau tidak dapat dilaksanakannya mediasi.

Dalam waktu paling lama 5 (lima) hari terhitung sejak penetapan sebagaimana dimaksud dalam pasal 20 ayat (5) para pihak dapat menyerahkan resume perkara ${ }^{14}$ kepada pihak lain dan Mediator. Dalam pertemuan yang disepakati, Mediator berhak meminta kepada para pihak untuk hadir langsung tanpa diwakili kuasa hukumnya. Dan apabila para pihak berhalangan hadir berdasarkan alasan yang sah sebagaimana di maksud dalam pasal 6 ayat (4), kuasa hukum dapat mewakili para pihak untuk melakukan mediasi dengan menunjukkan surat kuasa khusus yang memuat kewenangan kuasa hukum untuk mengambil keputusan, kuasa hukum wajib berpartispasi dalam proses mediasi dengan iktikad baik dan dengan cara yang tidak berlawanan dengan pihak lain atau kuasa hukunya.

Materi perundingan dalam mediasi tidak terbatas pada posita dan potitum gugatan, dalam pertemuan mediasi dilibatkan juga tokoh ahli dan tokoh masyarakat atas persetujuan para pihak/ atau kuasa hukum, Mediator dapat menghadirkan seorang atau lebih ahli, tokoh masyarakat, tokoh agama, atau tokoh adat. Dalam hal ini para pihak harus terlebih dahulu mencapai kesepakatan tentang kekuatan mengikat atau tidak mengikat dari penjelasan dan/atau penilaian ahli dan/ atau tokoh masyarakat. ${ }^{15}$ Jika mediasi berhasil mencapai kesepakatan maka para pihak dengan bantuan Mediatorwajib merumuskan kesepakatan secara tertulis dalam

\footnotetext{
${ }^{14}$ Resume Perkara adalah dokumen yang dibuat oleh para pihak yang memuat duduk perkara dan usulan penyelesaian sengketa. Lihat pasal 1 Ayat 7 PERMA Nomor 1 Tahun 2016.

15 Putusan Pasal 25 Peraturan Mahakamah Agung Nomor 01 Tahun 2016 Tentang Ruang lingkup Materi pertemuan mediasi.

Problematika Mediasi Dalam Kasus Perceraian|43
} 
kesepakatan perdamaian yang ditandatangani oleh para pihak dan Mediator. ${ }^{16}$

\section{Metodologi Penelitian}

Peneliti ini menggunakan jenis penelitian hukum Islam sosiologis, hukum dikonsepkan sebagai pranata sosial yang secara riil dikaitakan dengan variabel-variabel sosial yang lain. Apabila hukum sebagai gejala sosial yang empiris sifatnya, dikaji sebagai variabel bebas/ sebab yang menimbulkan pengaruh dan akibat dari berbagai aspek kehidupan sosial. Pengumpulan data menggunakanteknik studi dokumen, observasi dan wawancara.

\section{Analisis Problematika Mediasi di Mahkamah Syar'iyah Langsa}

PERMA Nomor 01 Tahun 2016 Tentang Prosedur Mediasi di Pengadilan memiliki kekuatan yang mengikat dan daya paksa terhadap para pihak yang berpekara di pengadilan. Dapat di lihat dengan apabila mediasi tidak di laksanakan maka putusan tersebut batal demi hukum. dengan demikian setiap para pihak yang berpekara di pengadilan wajib melalui proses mediasi terlebih dahulu sebagai upaya perdamain. ${ }^{17}$

Tujuan Mahkamah Agung membuat PERMA Nomor 01 Tahun 2016 ini untuk menyelesaikan permasalahan yang buntu agar tercapai jalan keluarnya. Jika dalam proses peradilan yang ingin dicapai adalah menang atau kalah (win or lost) namun dalam mediasi yang ingin dicapaai adalah keputusan yang menguntungkan kedua belah pihak (win win solution), inilah yang menjadikan mediasi sebagai upaya perdamaian menjadi jalan terbaik dalam menyeselaiakan permasalah yang ada. ${ }^{18}$

Peran penting yang dimiliki mediator mengharuskan mediator memiliki kemampuan yang

\footnotetext{
${ }^{16}$ Putusan Pasal 27 Peraturan Mahkamah Agung Nomor 01 Tahun 2016.

17 Wanwacara dengan Bukhari, Hakim dan Mediator Mahkamah Syar'iyah Langsa dan Rasyadi, Panitra Muda Jinayah Mahkamah Syar'iyah Langsa, Kota Langsa, Aceh pada tanggal 05 Desember 2017.

18 Wawancara dengan Bukhari, Hakim dan Mediator Mahkamah Syar'iyah Langsa, Kota Langsa, Aceh 05 Desember 20117.
}

baik sehingga proses mediasi dapat berjalan lancar. Baik dalam arti kata harus sesuai dengan ketentuan yang telah di tetapkan PERMA Nomor 01 Tahun 2016 Tentang prosedur mediasi di pengadilan. untuk memudahkan para pihak agar dapat berunding guna memilih meditor, sebagaimana yang telah di atur dalam PERMA. Pasal 19 PERMA Nomor 01 Tahun 2016 tentang Hak para pihak memilih mediator dalam mediasi di pengadilan yang berbunyi sebagai berikut:

"Para pihak berhak memilih seorang atau lebih mediator yang tercatat dalam daftar mediator di pengadilan".

Dari data yang diketahui, didapat bahwa Mediator Mahkamah Syr'iyah Langsa yang telah bersetifikat hanya sebanyak 2 (dua) orang dari 5 (lima) orang mediator yang ada dan hakim yang bersertifikat adalah bapak Salamat Nasution, S.H.I., M.A. dan bapak Dr.H. Abu Jahid Darso Atmojo, Lc., LL.M' dan tidak mungkin perkara itu di tumpukan pada mereka semua, karena keadaan yang membutuhkan mediator maka seluruh hakim yang berada di Mahkamah Syr'iyah Langsa diberdayaka sebagai mediator. ${ }^{19}$

Sertifikasi tidak juga menjamin keberhasilan mediasi, bahkan mediator yang tidak tersertifikasi pun ada juga yang berhasil. Keberhasilan mediasi lebih sering ditentukan dari bagaimana seorang mediator memperlakukan para pihak dan bagaimana mediator menyingkapi permasalahan yang ada. Strategi yang diuntukan oleh mediator untuk menadaikan para pihaak berfariasi sesuai dengan karakter mediator itu sendiri. Walaupun mediator yang telah tersertifikasi memiliki kemampuan yang lebih baik dari mediator yang belum tersertifikasi tidak meyakinkan kita bahwa mereka bisa mendamaikan para pihak yang berpekara, apalagi dalam persioalan perceraian pendirian para pihak yang sangat kuat dan sengketa yang telah berlarutlarut yang menjdikan keberhasilan mediasi tersebut

${ }^{19}$ Wanwacara dengan Bukhari, Hakim dan Mediator Mahkamah Syar'iyah Langsa, Kota Langsa, Aceh pada tanggal 05 Desember 2017.

Problematika Mediasi Dalam Kasus Perceraian|44 
sulit untuk di capai apalagi ini menyangkut tentang perasaan pribadi. ${ }^{20}$

Ketidak tersedianya mediator profesiaonal di luar hakim sangat mempengaruhi kinerja hakim, di mana hakim tersebut sudah bertugas untuk mengadili para pihak namun bertugas juga sebagai pendamai para pihak. Kerancuan ini yang menyebabkan timbulnya masalah dalam mediasi kasus perceraian di Mahkamah Syar'iyah Langsa. Para pihak menjadi di hadapkan pada figur yang sama dengan fumgsi dan kedudukan yang berbeda.

PERMA Nomor 01 Tahun 2016 tidak sepenuhnya di gunakan oleh Mahkamah Syar'iyah Langsa misalnya pada persoalan memilih mediator, dikatakan didalam PERMA bahwa 'para pihak berhak memilih mediatornya sendiri' tetapi jika pemilihan mediator dilakukan oleh para pihak maka ditakutkan akan terjadinya keterlambatan dalam mediasi karena keterbatasannya hakim mediator.Maka Mahkamh Syar'iyah mengambil alternatif lain pemilihan mediator dilakukan oleh Majlis hakim, dan para pihak tidak keberatan tetapi apabila para pihak keberatan maka baru di lakukan seperti yang tercantum di dalam PERMA Nomor 01 Tahun 2016. ${ }^{21}$

Semestinya Mahkamah Agung RI menyediakan Mediator profesiaonal yang tersertifikasi, hal ini bertujuan agar:

1. Agar mediator mampu berkerja maksimal, karena tidak juga bertugas sebagai hakim.

2. Lebih profesiaonal dan dapat bersahabat dengan para pihak, karena sebagai hakim mereka lebih menjaga wibawanya didepan para pihak, sedangkan mediator harus lebih dekat dan bersahbat dengan para pihak.

3. Agar lebih siyap menjadi mediator, karena sebagai profesiaonal mereka akan lebih memiliki waktu yang banyak dibanding dengan

${ }^{20}$ Wanwacara dengan Bukhari, Hakim dan Mediator Mahkamah Syar'iyah Langsa, Kota Langsa, Aceh pada tanggal 05 Desember 2017.

${ }^{21}$ Wanwacara dengan Bukhari, Hakim dan Mediator Mahkamah Syar'iyah Langsa, Kota Langsa, Aceh pada tanggal 05 Desember 2017. mediator hakim yang bertugas juga sebagai hakim.

Maka dapat penulis simpulkan bahwa seharusnya Mahkamah Agung lebih memperhatikan lagi dalam persoalan mediator, akibat dari keterbatasannya mediator yang handal hakim di Mahkamh Syr'iyah Langsa harus bertindak sebagai mediator yang menyebabkan kurangnya kepercayaan diri dalam menyelesaikan sengketa. Mahkamah Syar'iyah Langsa harus menyediakan mediator yang profesional di luar hakim, agar penanganan mediasi dijalankan dengan serius bukan hanya sebagai formalitas belaka.

Pada dasarnya sengketa yang sering di terima Mahkamah Syar'iyah Langsa kebanyakan adalah perkara perceraian, dimana yang disengketa bukanlah benda melainkan sengketa hati. Dengan demikian masalah yang dihadapi sangat sulit untuk difahami oleh pihak lain. para pihak lah yang lebih paham dan merasakan terhadap apa yang terjadi, sehinggaa proses mediasipun sangat tergantung pada sikap para pihak terhadap prosedur mediasi. Sehebat dan sekeras apapun usaha yang dilakukan oleh mediator, namun jika para pihak acuh terhadap proses mediasi maka hasilnya akan tetap tidak baik dalam arti kata mediasi tersebut gagal. ${ }^{22}$

Menerapkan sepenuhnya PERMA Nomor 01 Tahun 2016 merupakan tantangan terbesar bagi Mahkamah Syar'iyah Langsa.Terutama dalam hal Iktikad baik dalam mediasi,para pihak banyak yang keberatan tetang hal tersebut seperti yang disebutkan PERMA sebagai berikut:'apabila Tergugat tidak meghadiri mediasi maka tergugat di nyatakan tidak beriktikad baik,maka Tergugat akan dikenakan hukuman pembayaran uang mediasi', para pihak keberatan dalam hal tersebut, dikarenakan banyaknya beban biaya yang harus mereka tanggung.Maka dari itu Mahkamah syar'iyah mensiyasati dengan cara bagi Tergugat yang tidak menghadiri mediasi maka di kenakan biaya pangilan, selanjutnyasidang tetap berlangsung dan

\footnotetext{
${ }^{22}$ Wawancara dengan Rasyadi, Panitra Muda Jinayah Mahkamah Syar'iyah Langsa, Kota Langsa, Aceh pada tanggal 05 Desember 2017.
}

Problematika Mediasi Dalam Kasus Perceraian|45 
mediasi di ambil jangka waktu 15 (lima belas) hari untuk mediasi selanjutnya, tahap berikutnya para pihak baru membuat perjanjian dengan hakim mediator kapan para pihak ingin melakukan kembali mediasi, hakim tidak menentukan lagi, tugas hakim hanya menayakan pada saat sidang sealanjutnya.

Semenjak diterapkannya PERMA Nomor 01 Tahun 2016 di Mahkamah Syar'iyah Langsa belum ada terjadinya Gugatan yang tidak dapat diterima (niet ontvankeliijke verklaard/NO) di karenakan Penggugat tidak menghadiri medaisi, biasanya Penggugat dan Tergugat selalu hadir keduanya dan langsung terjadi mediasi pada hari itu juga, dan selesai atas kesepakatan kedua belah pihak dalam arti kata mediasi tersebut gagalmaka langsung di lakukan sidang selanjutnya pada keesokan harinya. ${ }^{23}$

Maka dari itu Mahkamah Syar'iyah memutuskan untuk tidak menerapkan sepenuhnya PERMA Nomor 01 Tahun 2016 ini karena ditakutkan tidak ada lagi biaya ringan dan sidang cepat, yang ada hanya menyusahkan masyarakat dalam mencari keadilan di pengadilan.

\section{Faktor Penghambat Mediasi di Mahkamah Syar'iyah Langsa}

Faktor penghambat yang sering terjadi dalam mediasi adalah sebagai berikut; pertama Konflik berkepanjangan yang dihadapi para pihak sudah terjadi sejak lama, bahkan berlarur-larut sehingga ketika proses mediasi di Mahkamah Syar'iyah dilakukan masing-masing pihak sudah tidak menerima lagi saran-saran dari luar. Biasanya para pihak sudah menempuh usaha damai di gampong tempat mereka berdimisili oleh tokoh masyarakat setempat, namun tetap saja tidak berhasil. Sehingga ketika sampai di Mahkamah Syar'iyah mereka sudah dengan usaha damai, yang menjadikan mereka menganggap itu tidak penting lagi; ${ }^{24}$ kedua, Faktor kejiawaan yaitu terhadap perkara perceraian, biasanya kekecewaan yang dalam terhdap pasangan

\footnotetext{
${ }^{23}$ Wanwacara dengan Bukhari, Hakim dan Mediator Mahkamah Syar'iyah Langsa, Kota Langsa, Aceh pada tanggal 05 Desember 2017.

${ }^{24}$ Wawancara dengan Rasyadi, Panitra Muda Jinayah Mahkamah Syar'iyah Langsa, Kota Langsa, Aceh pada tanggal 05 Desember 2017.
}

mengakibatkan keputusasaan dari para piihak untuk tidak kembali membina rumah tangga seperti sediakala. Sengketa lain biasanya mengenai harta, rasa di zalimi sehingga merasa tidak adil menjadikan para pihak beranggapan bahwa keputusan Mahkamah Syar'iyahlah yang paling tepat dan adil $;{ }^{25}$ ketiga, Sikap dan peran para pihak dalam mengikuti proses mediasi sangat berpengaruh terhadap hasil medaisi tersebut. sikap acuh dari para pihak menjadikan mediasi upaya yang di tempuh sia-sia. Para pihak beranggapan mediasi sebagai firmalitas dan prosedur yang harus dijalani katika berpekara di Mahkamh Syar'iyah. ${ }^{26}$

\section{Penutup}

Prosedur mediasi di Mahkamah Syar'iyah Langsa dapat di laksanakan pada saat sidang pertama Majlis Hakim akan melengkapi berkas -berkas yang diperlukan dalam persidangan, seperti kelengkapan surat gugatan, surat kuasa, surat panggilan para pihak, dsb. Selanjutnya Hakim akan menjelaskan bahwa sesuai prosedur dimana sebelum dijalankannya proses cerai maka para pihak di wajibkan mengadakan mediasi. Hakim akan menentukan seorang mediator untuk memimpin mediasi para pihak. Majlis Hakim kemudian menentukan hakim lain untuk menjadi mediator dalam pelaksanan mediasi tersebut, Medaiasi Umumnya di Lakukan Maksimal 2 kali, Bila dalam mediasi tidak tercapai perdamaian/rujuk, maka barulah proses perkara perceraian dapat dilkasanakan; kedua,

Sedangkan problematika mediasi dalam kasus perceraian di Mahkamah Syariyah Kota Langsa terdapat bebarapa poin, diantaranya; Pertama, Kualitas Hakim yang di tunjuk sebagai mediator belum memadai. hakim yang mengikuti pelatihan mediator yang diselengarakan oleh Mahkamah Agung hanya 2 (dua) orang dari 5 Hakim yang ada di Mahkamah Syar'iyah Langsa yang menjadi mediator. Serta tidak tersedianya mediator

${ }^{25}$ Wanwacara dengan Bukhari, Hakim dan Mediator Mahkamah Syar'iyah Langsa dan Rasyadi, Panitra Muda Jinayah Mahkamah Syar'iyah Langsa, Kota Langsa, Aceh pada tanggal 05 Desember 2017.

26 Wanwacara dengan Bukhari, Hakim dan Mediator Mahkamah Syar'iyah Langsa, Kota Langsa, Aceh pada tanggal 05 Desember 2017.

Problematika Mediasi Dalam Kasus Perceraian|46 
profesional yang memiliki waktu lebih banyak dari pada Hakim yang menjadi mediator; kedua, Waktu yang tidak dimanfaatkan secara maaksimal. Waktu yang ditentukan oleh PERMA adalah 30 (tiga puluh) hari kerja dan jika belum berhasil dapat diperpanjang selama 30 (tiga puluh) hari terhitung sejak berakhirnya jangka waktu hari kerja mediasi hal ini juga menjadi kendala dalam mediasi karena disebabkan oleh beberapa factor antara lain; pertama, diperpanjang selama 30 (tiga puluh) hari terhitung sejak berakhirnya jangka waktu hari kerja mediasi hal ini juga menjadi kendala dalam mediasi karena disebabkan oleh beberapa factor antara lain; pertama, Kepatuhan para pihak yang sangat rendah menjadi salah satu faktor yang membuat Mahkamah Syar'iyah Langsa kesulitan dalam menerapkan PERMA yang sebagaimana seharusnnya, salah satunya tentang 'Iktikad baik' besarnya kisaran biaya dikarenakan hal tersebut membuat masyarakaat keberatan terhadap peraturaan yang sudah dikeluarka oleh Mahkamah Agung tersebut; kedua, Ketidakpeduliannya masyarakat pada mediasi. Mereka mengangap mediasi sebagai pelengkap untuk menyelesaikan sengketa mereka dalam proses persidangan di Mahkamah Syar'iyah Langsa.

\section{Daftar Pustaka}

Ketua Mahkamah Agung Republik Indonesia, Peraturan Mahkamah Agung Nomor 1 Tahun 2016 Tentang Prosedur Mediasi di Pengadilan.

Kevin Angkouw, "Fungsi Mahkamah Agung Sebagai Pengawas Internal Tugas Hakim Dalam Proses Peradilan", Lex Administratum II, 2 (April-Juni 2014): 1-2.

Manan, Abdul. Penerapan Hukum Acara Perdata Di Lingkungan Peradilan Agama. Jakarta: Kencana. 2008.
Putusan Pasal 17 Peraturan Mahkamah Agung Nomor 01 Tahun 2016 Tentang tahapan pramediasi.

Putusan Pasal 25 Peraturan Mahakamah Agung Nomor 01 Tahun 2016 Tentang Ruang lingkup Materi pertemuan mediasi.

Putusan Pasal 8 Peraturan Mahkamah Agung Nomor

01 Tahun 2016 Tentang Biaya jasa Mediator.

Undang-Undang Nomor 48 Tahun 2009 Tentang Pembentukan Peraturan Perundang-undangan.

Undang-Undang Nomor 48 Tahun 2009 Tentang Perubahan atas Undang-Undang Nomor 14 Tahun 1985 Teantang Mahkamah Agung.

Putusan Pasal 27 Peraturan Mahkamah Agung Nomor 01 Tahun 2016.

\section{Data Tambahan}

Wawancara dengan Bukhari, Hakim dan Mediator Mahkamah Syar'iyah Langsa, Kota Langsa, Aceh pada tanggal 05 Desember 2017.

Wawancara dengan Rasyadi, Panitra Muda Jinayah Mahkamah Syar'iyah Langsa, Kota Langsa, Aceh pada tanggal 05 Desember 2017. 